\title{
A new fossil species of Trentepohlia (Diptera, Limoniidae) from the Dominican Miocene
}

\author{
Jorge MEDEROS \\ Museu de Ciències Naturals de Barcelona, Passeig Picasso s/n, 08003, Barcelona (SPAIN) \\ mederos@gmail.com (corresponding author) \\ Yinan WANG \\ Yinan, Box 2882, 1301 S Fern St, Arlington VA 22202 (USA) \\ Susana DUQUE-VALERO \\ Marc CAMPENY
}

Museu de Ciències Naturals de Barcelona, Passeig Picasso s/n, 08003, Barcelona (SPAIN)

Submitted on 15 May 2019 | Accepted on 28 January 2020 | Published on 24 November 2020

urn:Isid:zoobank.org:pub:15ECF9C4-32B5-46C7-96E4-790649C5B1B8

Mederos J., Wang Y., Duque-Valero S. \& Campeny M. 2020. - A new fossil species of Trentepohlia (Diptera, Limoniidae) from the Dominican Miocene. Zoosystema 42 (29): 583-592. https://doi.org/10.5252/zoosystema2020v42a29. http://zoosystema.com/42/29

\section{ABSTRACT}

We present the description of a new species of Limoniidae Rondani, 1856. Trentepohlia (Paramongoma) miocenica Mederos \& Wang n. sp. is described from resinites (little or poorly polymerized amber) of Yanigua Formation, in the Eastern District of Dominican Republic, well differentiated from the other species from the fossil record of Hispaniola to date, Trentepohlia (Paramongoma) agri Podenas \& Poinar, 1999. A key to the five fossil species of the subgenus Paramongoma Brunetti, 1911 described to date is also offered. Since the biology of the immature stages of Paramongoma are associated with

KEY WORDS

Dominican Republic,

Hispaniola,

Paramongoma,

resinites,
Yanigua Formation, new species.

MOTS CLÉS Ambre,

République dominicaine,

Hispaniola

Paramongoma,

formation de Yanigua, nouvelle espece. aquatic microhabitats (such as phytotelmata and small mountain streams), the occurrence of such microhabitats can therefore be hypothesized in the area then occupied by the Hispaniolan paleo-island. The records of extant species of the subgenus Paramongoma from several islands of the Lesser and Greater Antilles, as well as presence of the suitable ecological conditions, offers the possibility of finding living species of Trentepohlia Bigot, 1854 at Hispaniola, which is currently the only large island in the Caribbean without records of the genus.

\section{RÉSUMÉ}

Une nouvelle espèce fossile de Trentepohlia (Diptera, Limoniidae) du Miocène de la Dominique. Nous présentons la description d'une nouvelle espèce de Limoniidae Rondani, 1856. Trentepohlia (Paramongoma) myocénique Mederos \& Wang n. sp., décrite à partir d'une résinite (ambre peu ou mal polymérisée) de la formation de Yanigua, située dans le district oriental de la République dominicaine, bien différenciée de la seule espèce connue des archives fossiles d'Hispaniola, Trentepohlia (Paramongoma) agri Podenas et Poinar, 1999. Une clé séparant les cinq espèces fossiles du sous-genre Paramongoma Brunetti, 1911 décrites à ce jour est proposée. Comme la biologie des stades immatures de Paramongoma est associée à des microhabitats aquatiques (tels que les phytotelmata et des petits ruisseaux de montagne), on peut faire l'hypothèse que ces types de microhabitats étaient présents dans la zone alors occupée par la paléo-île d'Hispaniola. Les signalisations connues des espèces actuelles du sous-genre Paramongoma dans plusieurs îles des Petites et Grandes Antilles, ainsi que l'existence de conditions écologiques favorables, offrent la possibilité de trouver des espèces vivantes à Hispaniola, alors que cette île est la seule grande île de la Caraîbe sans mention du genre Trentepohlia Bigot, 1854. 


\section{INTRODUCTION}

The family Limoniidae Rondani, 1856, with a wide distribution throughout the globe (except Antarctica) currently has almost 10700 described species (Oosterbroek 2019). Trentepoblia Bigot, 1854, a genus within Limoniidae, accounts around 309 living species described from around the world (grouped into seven subgenera), and is also present in the fossil record with 10 species recorded up to now (Arillo \& Ortuño 2005; Evenhuis 2014; Oosterbroek 2019; Ngô-Muller et al. 2019). At present, five extant species of Trentepohlia are recorded from the Antilles (Mederos-López \& Gelhaus 2014; Oosterbroek 2019), belonging to the subgenera Mongoma Westwood, 1881 and Paramongoma Brunetti, 1911 (Table 1). No living species is known from Hispaniola, the island that encompasses Haiti and the Dominican Republic, a territory with a great diversity of environments and the second largest island after Cuba. From deposits of resinites (amber, copal) of the Dominican Republic, Trentepohlia (Paramongoma) agri Podenas \& Poinar, 1999 has been described. From the fossil record, four species of Trentepohlia are placed within the subgenus Paramongoma (Table 1). In the present work, we offer the description of a new species of Trentepoblia (Paramongoma) from the fossil record of the Dominican Republic, coming from resinites from the eastern region, specifically the Yanigua formation, which allows us to propose an accurate dating of the pieces.

In this sense, the large database of fossil plants and animals in resinites from the Dominican Republic is currently the world's best source of terrestrial invertebrate fossils derived from a tropical ecosystem (Grund 2006). Poinar \& Poinar (1999) outlined a reconstruction of the Miocene Dominican amber forest, reaching the conclusion that the ecosystem on Hispaniola changed since amber times; many taxa are now extinct from the island, stingless bees for example, but are present in Dominican amber (Michener \& Poinar 1996), and there is no remaining forest on Earth today with such a community of plants and animals. This scenario of replacement of fauna in Hispaniola from the Miocene to the present was also observed by Wilson (1988) when studying and comparing the fauna of living ants and those present in the fossil record. On the other hand, Grund (2006) after studying several genera of Chironomidae Newman, 1834 (Diptera) present in Dominican amber, shows evidence of stability at least in certain ecosystems present on the island. Also, Sherratt et al. (2015) found that the primary axes of ecomorphological diversity in the Hispaniolan anole fauna appear to have changed little between the Miocene and the Present, providing evidence for the stability of ecological communities over macroevolutionary timescales.

\section{MATERIAL AND METHODS}

\section{Geological setting}

Amber deposits are distributed along several localities from the Greater Antilles (Fig. 1) such as Puerto Rico, Jamaica and the Hispaniola Island. Most of these deposits do not present significant economic value, with the exception of the Dominican Republic, which has a significant quality and has been much appreciated throughout history (Iturralde-Vinent \& Hartstein 1998).

Amber deposits of the Dominican Republic, mostly associated with lignite, are found in late Middle Miocene sedimentary sequences associated with subaerial to deep-marine depositional environments (Mann et al. 1991). The most significant amber deposits are located in the north of Santiago de los Caballeros and the north-eastern area of Santo Domingo (Vaughan et al. 1922), where the exploitation of amber is carried out by artisanal mining. These two amber mining districts are generally referenced in the literature as the Northern Area and the Eastern Area, respectively (Iturralde-Vinent \& MacPhee 1996; Iturralde-Vinent 2001). The present work is based on the study of resinites samples collected in the Eastern Area deposits (Fig. 1), and directly associated with the sedimentary detrital materials of the northern Yanigua Formation (Brouwer \& Brouwer 1982; Iturralde-Vinent \& MacPhee 1996; Iturralde-Vinent 2001).

The Yanigua Formation is a detrital sequence $100 \mathrm{~m}$ thick dated as late Early to early Middle Miocene (20-15 Ma) (Berggren et al. 1995). It is composed of the alternation of clays and laminated sandy clays, along with lignite and minor conglomerates. According to Iturralde-Vinent (2001), the Yanigua Formation represents the depositional scenario in low-energy lagoon and coastal swamp environments. The reduced amount of detritus in the Yanigua Formation would indicate that erosion was not very extensive and that the soil and organic litter were mostly removed only during rainstorms. Amber is found as irregular flattened nodules, usually distributed as pockets or lenses ranging from a few millimetres to several centimetres in size and mainly occurring in the shallower part of the Yanigua succession (Champetier et al. 1982; Iturralde-Vinent \& Hartstein 1998).

\section{Main features of Dominican amber}

Resin-producing trees are widely distributed in the tropics, but Dominican amber was probably derived from the resin of the extinct leguminous tree Hymenaea protera Poinar, 1991. Even though amber from the Yanigua Formation is more polymerized and dense than resinites from Cuba or Puerto Rico (Iturralde-Vinent 2001), it presents anomalous physical properties in comparison to common amber samples worldwide. Physical properties of the amber from Yanigua Formation have been studied in the present work and it can be summarized as follows (see detailed values in Table 2). The studied samples from the Yanigua Formation are warm to touch and smell like a pine tree after being penetrated with a hot metal needle. These qualitative features also confirm that these resinites have a natural origin. In some samples there are air bubbles caused during the insect immersion or movement (Fig. 2B) that can also be preserved during the diagenesis (MZB 2019-0719, MZB 2019-0723). There are also biphasic inclusions with air and water (MZB 2019-0719, MZB 2019-0720), probably 


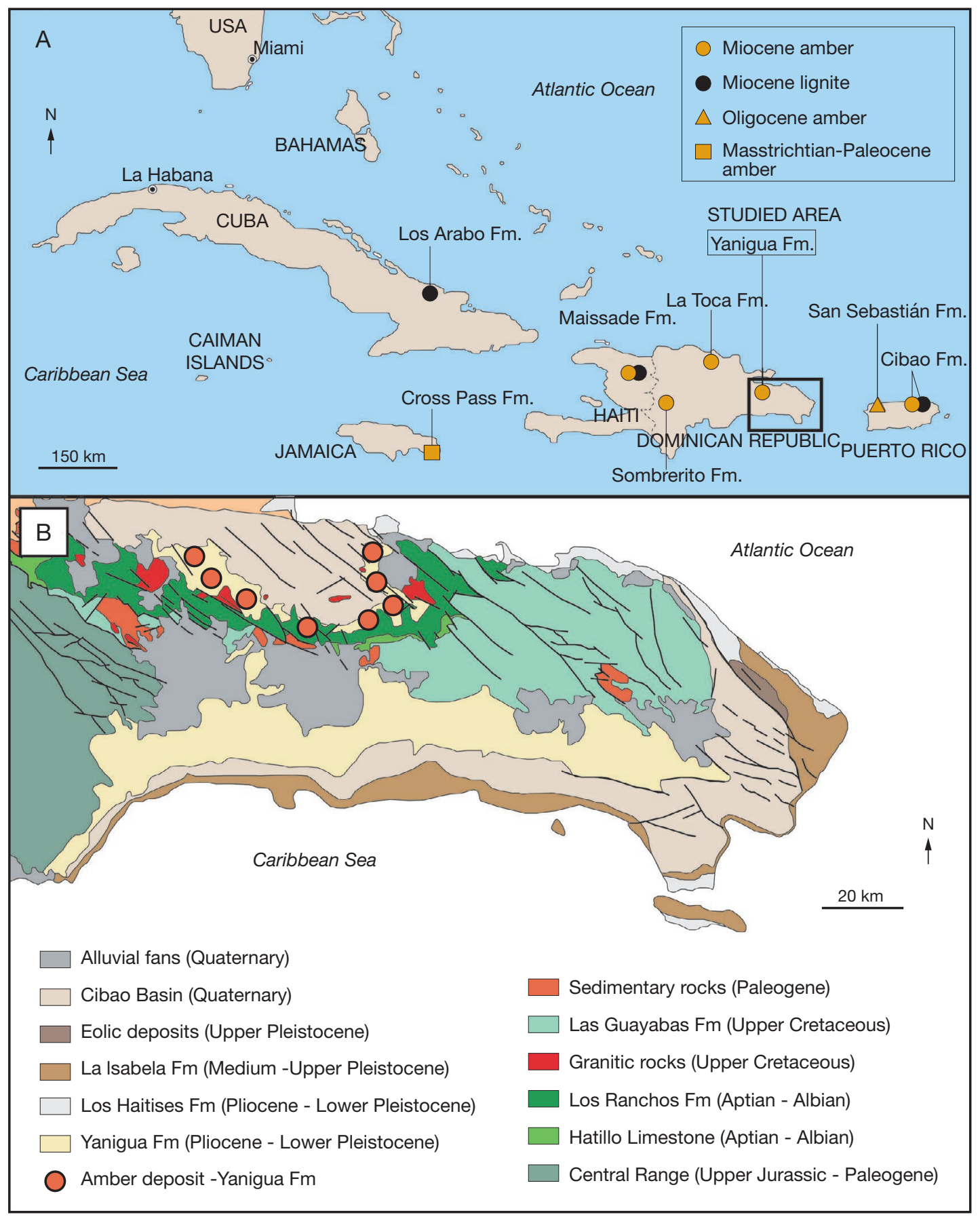

FIG. 1. - Geographical location of the studied area (A), as well as the main amber and lignite deposits from the West Indies, and general geological map (B) of the eastern region of the Dominican Republic and location of the amber deposits associated to the Yanigua Formation (modified from Iturralde-Vinent 2001; Díaz-Neira et al. 2017).

related with the formation of amber in a lagoon environment (Iturralde-Vinent 2001).

As mentioned above, common amber differs from copal and other resins due to its resistance to organics solvents. The studied amber from the Yanigua Formation reacts to acetone (Grimaldi 1995), which added to its low specific gravity, suggests that it is low polymerized probably due to the lack of significant diagenetic process during burial (Iturralde-Vinent \& Hartstein 1998).
The material studied here comes from a mine in El Valle, located in the Eastern Cordillera, Yanigua formation, Dominican Republic. The specimens are preserved in little polymerized resinites, a usual feature for the pieces coming from this formation. A total of six pieces of resinites with Tentrepohlia fossils in the collections of Museu de Ciències Naturals de Barcelona (MCNB), Catalonia (Spain) were examined. The pieces were cut and grounded for observation with classical microscope techniques (stereomicroscopy and light micros- 
TABLE 1. - Extant species of Trentepohlia Bigot, 1854 recorded in the Antilles and fossil species of Trentepohlia (Paramongoma) Brunetti, 1911 described worldwide.

\begin{tabular}{|c|c|c|c|}
\hline Species & extant & fossil & distribution \\
\hline Trentepohlia (Mongoma) inexpectata Mederos-López \& Gelhaus, 2014 & $\times$ & & Cuba \\
\hline Trentepohlia (Paramongoma) agri Podenas \& Poinar, 1999 & & $\times$ & Dominican Rep. (Miocene) \\
\hline Trentepohlia (P.) dominicana Alexander, 1947 & $\times$ & & Dominica, Puerto Rico \\
\hline Trentepohlia (P.) dzeura Podenas \& Poinar, 2009 & & $\times$ & Burma (Lower Cretaceous) \\
\hline Trentepohlia $(P$.$) immemorata Podenas \& Poinar, 2001$ & & $x$ & Mexico (Miocene) \\
\hline Trentepohlia (P.) manca (Williston, 1896) & $\times$ & & St. Vincent \\
\hline Trentepohlia (P.) mexicana Podenas \& Poinar, 2001 & & $x$ & Mexico (Miocene) \\
\hline Trentepohlia (P.) miocenica n. sp. & & $x$ & Dominican Rep. (Miocene) \\
\hline Trentepohlia (P.) niveitarsis (Alexander, 1913) & $\times$ & & Jamaica, Puerto Rico \\
\hline Trentepohlia (P.) pallida (Williston, 1896) & $\times$ & & St. Vincent \\
\hline
\end{tabular}

TABLE 2. - Physical properties of common amber with the calculated physical properties of the samples studied. Notes: 1, standard physical properties of common amber (Schumann 2001); 2, calculated in hydrostatic balance applying the principle of Archimedes and extrapolating result with an average of 5 measurement.

\begin{tabular}{|c|c|c|c|c|c|c|c|c|c|}
\hline Sample & Hardness & $\begin{array}{l}\text { Specific } \\
\text { Gravity2 }\end{array}$ & Fracture & Colour & $\begin{array}{l}\text { Refractiv } \\
\text { Index }\end{array}$ & $\begin{array}{l}\text { Optical } \\
\text { Charact }\end{array}$ & rAnisotropy & Transparency & $\begin{array}{l}\text { Fluorescence } \\
\text { y (long wave) }\end{array}$ \\
\hline Amber ${ }^{1}$ & $2-2.5$ & $\begin{array}{r}1.050- \\
1.100\end{array}$ & conchoidal & $\begin{array}{l}\text { yellow, } \\
\text { orange, } \\
\text { brown, blue }\end{array}$ & $\begin{array}{l}1.539 \text { to } \\
1.545\end{array}$ & isotropic & anomaly & $\begin{array}{l}\text { transparent } \\
\text { to opaque }\end{array}$ & $\begin{array}{l}\text { common moderate } \\
\text { to strong bluish-white } \\
\text { to yellow-green }\end{array}$ \\
\hline $\begin{array}{l}\text { MZB 2019-0707 } \\
\text { (holotype) }\end{array}$ & 2 to 3 & 1.040 & conchoidal & pale yellow & 1.540 & isotropic & anomaly & transparent & $\begin{array}{l}\text { very shallow, from weak } \\
\text { to moderate intensity } \\
\text { in white-bluish colour. }\end{array}$ \\
\hline MZB 2019-0716 & 2 to 3 & 1.044 & conchoidal & pale yellow & 1.542 & isotropic & anomaly & transparent & $\begin{array}{l}\text { very shallow, from weak } \\
\text { to moderate intensity } \\
\text { in white-bluish colour. }\end{array}$ \\
\hline MZB 2019-0719 & 2 to 3 & 1.047 & conchoidal & yellow & 1.539 & isotropic & anomaly & transparent & $\begin{array}{l}\text { very shallow, from weak } \\
\text { to moderate intensity } \\
\text { in white-bluish colour. }\end{array}$ \\
\hline MZB 2019-0720 & 2 to 3 & 1.050 & conchoidal & orange & 1.540 & isotropic & anomaly & transparent & $\begin{array}{l}\text { very shallow, from weak } \\
\text { to moderate intensity } \\
\text { in white-bluish colour. }\end{array}$ \\
\hline MZB 2019-0723 & 2 to 3 & 1.052 & conchoidal & yellow & 1.540 & isotropic & anomaly & transparent & not present. \\
\hline MZB 2019-0726 & 2 to 3 & 1.051 & conchoidal & yellow & 1.542 & isotropic & anomaly & transparent & $\begin{array}{l}\text { very shallow, from weak } \\
\text { to moderate intensity } \\
\text { in white-bluish colour. }\end{array}$ \\
\hline
\end{tabular}

copy). The transparency of the pieces is exceptional though in a few occasions the observation and photography of the key structures were difficult. Specimens were examined with Motic SMZ-168 Zoom Stereo Microscope, Kyowa Unilux-12 83-483D, and images were taken by multi-stack with iPhone SE and processed with Helicon Focus 6. Measurements were made with an ocular reticule. We adopt the classification of Starý (1992), also followed by the Catalog of the Craneflies of the World (Oosterbroek 2019), with Trentepohlia within the family Limoniidae. The morphological terminology mainly follows that of Gelhaus (2009) and Cumming \& Wood (2009). All the specimens are deposited in the MCNB, and for each specimen the assigned registration number is indicated preceded by the former institution acronym, MZB.

Analyses of physical features of the studied resinites were carried out at the Mineralogy Department from the MCNB. The study of microscopic textures and inclusions was carried out using Optika LAB-20 Zoom Stereo Microscope equipment. To determine refractive index of resinite samples, the specimens have been analyzed using a gemmological glassrefractometer Shibuya $160 \mathrm{M}$ and fluorescence measurements were obtained using a UV-lamp with long wave of $366 \mathrm{~nm}$.

\section{ABBREVIATIONS \\ Veins \\ $\mathrm{A}_{1} \quad$ anal vein; \\ $\mathrm{CuA}_{1}, \mathrm{CuA}_{2}$ anterior branches of cubitus; \\ $\mathrm{M}_{1+2}, \mathrm{M}_{3} \quad$ posterior branches of media; \\ $\mathrm{R}_{1}, \quad$ anterior branch of radius; \\ $\mathrm{R}_{2}, \mathrm{R}_{3}, \mathrm{R}_{4+5}$ posterior branches of radius; \\ Rs radial; \\ Sc subcosta.}

Cells

$\mathrm{r}_{1}, \mathrm{r}_{2}$ and $\mathrm{r}_{3}$, radial.

\section{Institutions \\ MCNB Museu de Ciències Naturals de Barcelona (formerly MZB).}

\section{SYSTEMATIC PALAEONTOLOGY}

A total of seven male specimens of Trentepohlia (Paramongoma), of variable preservation status, were available for examination. As a result of this study, a key to the identification of the five known fossil species of the subgenus Paramongoma is offered below, based only on male specimens. 
Family LimONIIDAE Rondani, 1856

Genus Trentepohlia Bigot, 1854

Trentepohlia Bigot, 1854: 456, 473.

TYPE SPECIES. - Limnobia trentepohlii Wiedemann, 1828 (as

"Trentepoblia limnobioides"), by monotypy.

Subgenus Paramongoma Brunetti, 1911

Paramongoma Brunetti, 1911: 295.

TYPE SPECIES. —Cylindrotoma albitarsis Doleschall, 1857, by original designation.

\section{Trentepoblia (Paramongoma) miocenica} Mederos \& Wang n. sp.

(Figs 2-4)

\section{urn:Isid:zoobank.org:act:059E96DC-09D1-478C-AAFC-81146CF79C28}

Type Material. - Holotype. Dominican Republic • $0^{x}$; MZB 2019-0707; Mine in El Valle, Eastern Cordillera, Yanigua formation; Y. Wang leg. [syninclusions: seven specimens of Cecidomyiidae (MZB 2019-0708 to MZB 2019-0714) and one Ceratopogonidae MZB 2019-0715 (all Diptera)].

Paratypes. Dominican Republic • 2 ơ; MZB 2019-0716, MZB 2019-0717; same data as for holotype; [syninclusions: one specimen Coleoptera, MZB 2019-0718] • 1 ơ; MZB 2019-0719; same data as for holotype $11 \mathrm{O}^{7}$; MZB 2019-0720; same data as for holotype; [syninclusions: one Formicidae specimen (Hymenoptera) MZB 20190721 and one Hemiptera specimen (fragments) MZB 2019-0722] - 1 specimen unknown sex (presumably male, terminalia destroyed by the polishing of the piece); MZB 2019-0723; same data as for holotype [syninclusions: one specimen Keroplatidae MZB 2019-0724 (Diptera) and one specimen Parasitica (Hymenoptera) MZB 2019-0725] • $10^{2}$ (terminalia partially destroyed by the polishing of the piece); MZB 2019-0726; same data as for holotype [syninclusions: one specimen Ceratopogonidae MZB 2019-0727 (Diptera)].

DiAgNOSIS. - The species is characterized by a dark brown, wellmarked stigma on the hyaline wing and accompanied (surrounded) by a pale brown area that spans the stigmatic region and cells $r_{1}$, $r_{2}$ and $r_{3}$, and also by a single gonostylus, narrow at its base with a small and slender tooth shape lobe, and lanceolate in its apical half.

ETHYMOLOGY. - This interesting fossil species takes its name from the Miocene, the geological epoch from which it proceeds, a latinized adjective.

\section{DESCRIPTION}

Male (holotype)

Length. Body (without antennae) $4.5 \mathrm{~mm}$ (Fig. 2B); antennae $1.1 \mathrm{~mm}$ (Fig. 3C); wing $3.8 \mathrm{~mm}$ (Fig. 3A, B).

Head. Brown. Compound eyes completely covering the head, holoptic. Antenna 16 segmented (Fig. 3C), brown throughout. Scape four times as long as wide, pedicel oval and about half the length of the scape. Flagellomeres 1-8 ovoids, 9-14 slightly elongate. Flagellomere 1 greater than the rest, shorter than pedicel. Apical flagellomere longer than the preceeding flagellomere. Flagellomeres with verticils in their middle part, slightly shorter than the respective flagellomeres.

Thorax. Completely brown (Fig. 4B, C), without showing any evident pattern of stripes on the prescutum, scutum or pleura (in one of the paratypes, the pleura a slightly lighter brown). Coxae and legs completely brown throughout. Halters brown.

Wings (Fig. 3A, B). Translucent with a dark brown, wellmarked stigma accompanied (surrounded) by a pale brown area that spans the stigmatic region and cells $\mathrm{r}_{1}, \mathrm{r}_{2}$ and $\mathrm{r}_{3}$; length of $\mathrm{R}_{2}$ greater than $\mathrm{R}_{3} ; \mathrm{R}_{\mathrm{s}}$ almost straight, almost four times the length of bm-cu; $R_{4}+5$ just over eight times the length of $\mathrm{R}_{3}$; length of $\mathrm{bm}$-cu less than the distance between the distal ends of $\mathrm{CuA}_{2}$ and $\mathrm{A}_{1}$.

Abdomen. Brown throughout. Hypopygium brown (Fig. 4A). Gonocoxites conical in shape, twice as long as wide. Gonostylus single, as long as the gonocoxite, narrow at its base and lanceolate in its apical half, with a small and slender tooth shape lobe located in the basal half, approximately a quarter the length of the gonostylus (Fig. 4A).

\section{Female. Unknown.}

Distribution and Age. - Dominican Republic resinites, Miocene (16-15 Ma).

\section{REMARKS}

When analyzing the male terminalia of Trentepoblia miocenica Mederos \& Wang n. sp. similarities are observed with T. agri, the only other species of the subgenus present in the fossil record of Hispaniola, specifically the presence of a lobe or projection in the basal half of the gonostylus. It is noteworthy that wide and lanceolate form of the apical half of the gonostylus in T. miocenica Mederos \& Wang n. sp. differs markedly from the more slender and pointed form shown by T. agri. However, these two species can be easily differentiated by the presence of a well-marked dark brown stigma on the wing of T. miocenica Mederos \& Wang n. sp., absent in the totally translucent wing of T. agri. Another diagnostic feature of T. miocenica Mederos \& Wang n. sp. is the apical flagelomere of the antenna longer than the previous one (equal in T. agri). On the other hand, the characteristics of the male terminalia of $T$. miocenica Mederos \& Wang n. sp., as well as the smaller size of the first flagelomere with respect to the pedicel, easily separate this species from the other two closely related species $T$. immemorata and T. mexicana, both from the [Chiapas amber] Miocene of Mexico. Although T. immemorata, T. mexicana and T. miocenica Mederos \& Wang n. sp. share the characteristic of having a well-marked stigma, they show marked differences in wing venation. 

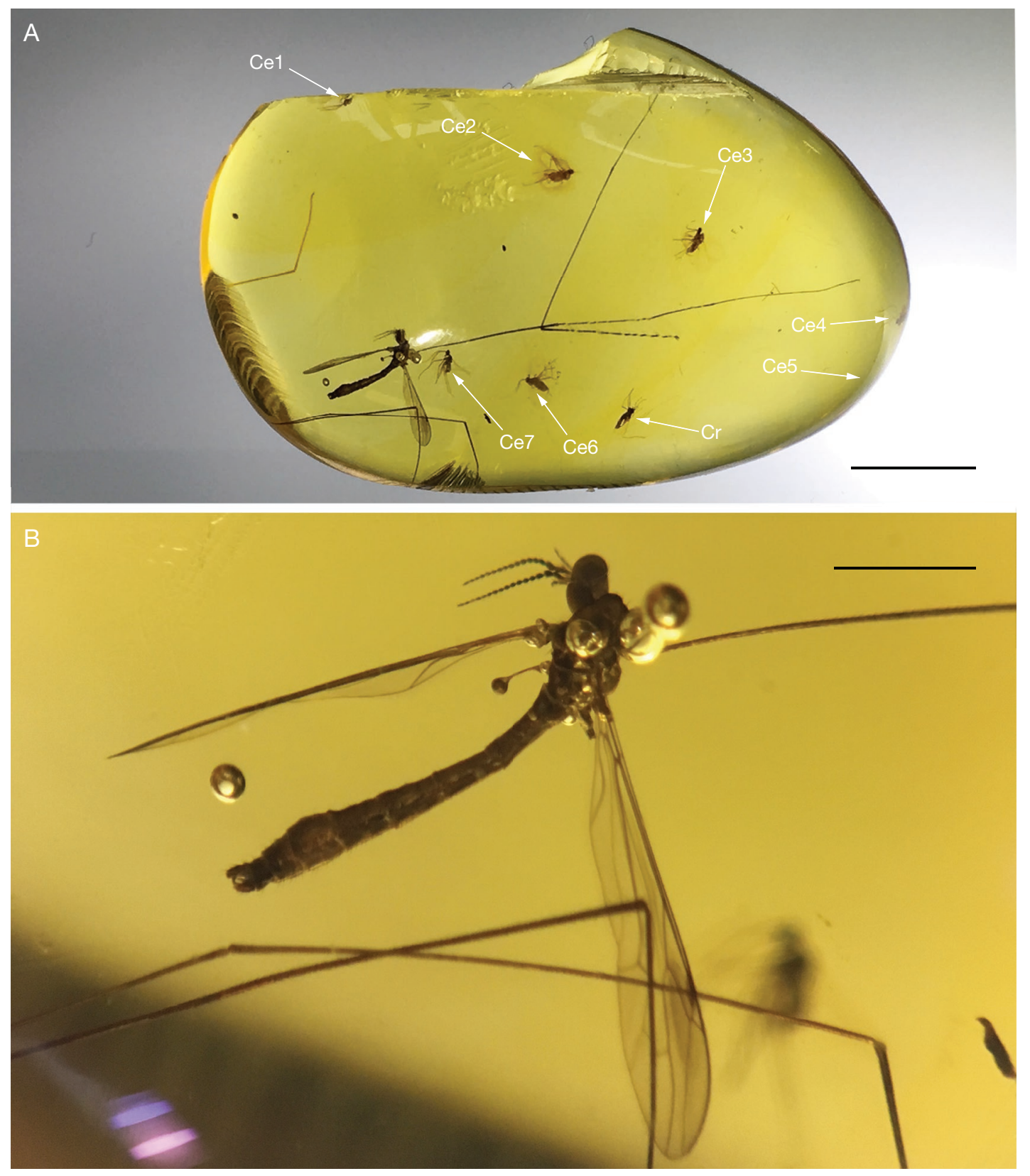

FIG. 2. - A, general configuration of the syninclusion of the resinite piece with Trentepohlia (P.) miocenica Mederos \& Wang n. sp. holotype specimen, Cecidomyiidae $(\mathbf{C e})$ and Ceratopogonidae (Cr) specimens; B, habitus of the male specimen (holotype) of T. miocenica Mederos \& Wang n. sp. Scale bars: A, 5 mm; B, 1 mm.

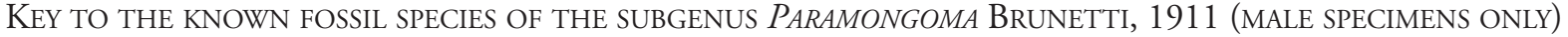

1. Wing with well-marked dark brown stigma ............................................................................. 2

— Wing clear, translucent, without or with at most weakly marked stigma ............................................ 4

2. Wing with small brownish stigma; antenna with the first flagellomere longer than the pedicel ................... 3

- Wing with dark brown stigma surrounded by a large, pale brown area; antenna with the first flagellomere shorter than the pedicel ........................................ Trentepohlia (Paramongoma) miocenica Mederos \& Wang n. sp.

3. Gonostylus with large blunt tooth in the basal half ................ T. (P.) immemorata Podenas \& Poinar, 2001. — Gonostylus without tooth in the basal half ..................................... T. (P.) mexicana Podenas \& Poinar, 2001.

4. Eighth tergite of abdomen with wide and deeply emarginated posterior margin; antenna with apical flagellomere longer than preceding segment T. (P.) dzeura Podenas \& Poinar, 2009.

- Eighth tergite of abdomen simple, without additional structures; antenna with apical flagellomere as long as preceding segment T. (P.) agri Podenas \& Poinar, 1999. 

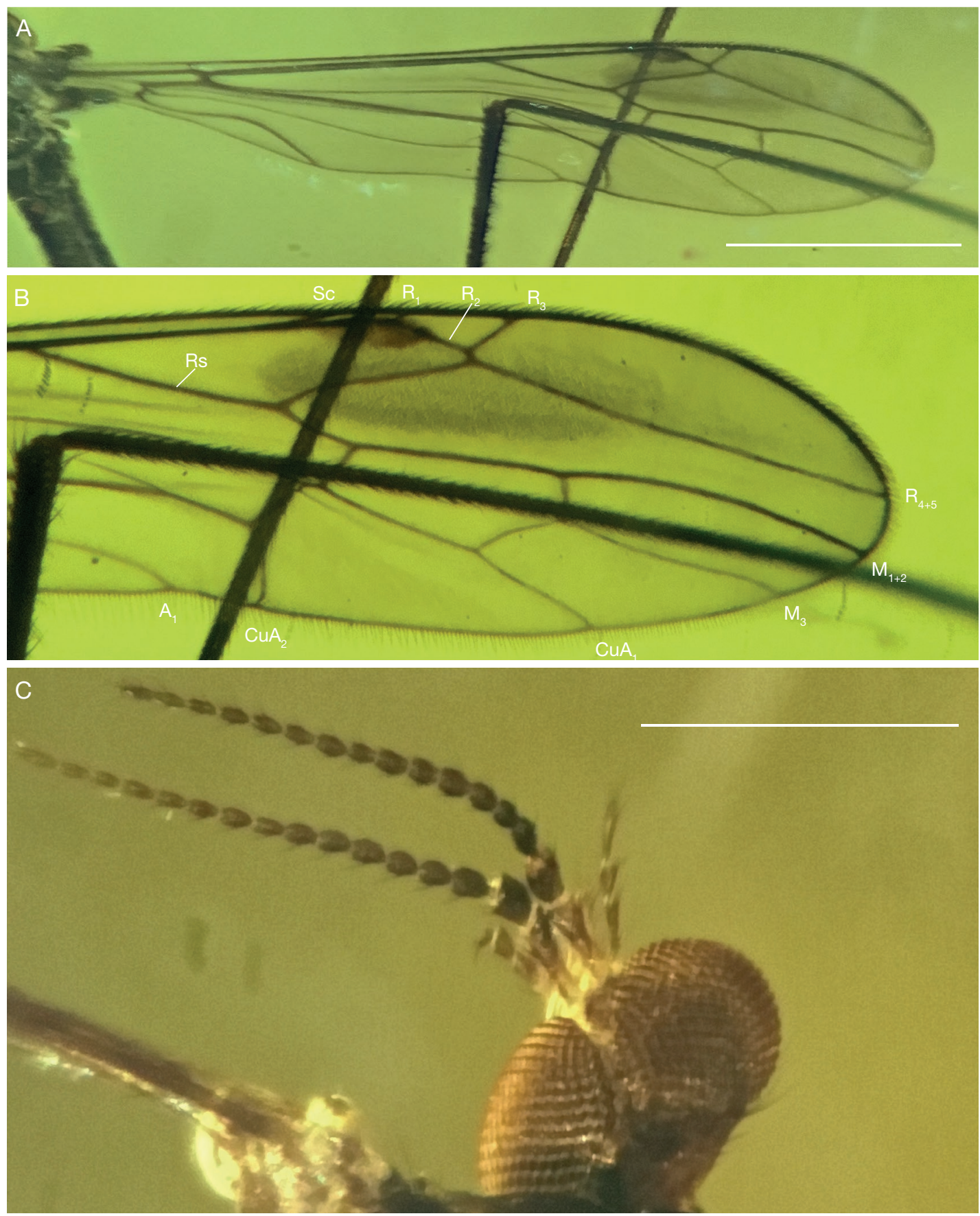

FIG. 3. - Wing venation (A, B), head and antenna (C) of Trentepohlia (P.) miocenica Mederos \& Wang n. sp. holotype specimen. Scale bars: A, 1 mm; B, not to scale; C, $0.5 \mathrm{~mm}$.

\section{DISCUSSION}

While the biology and the immature states of the subgenus Mongoma remains unknown (De Jong 2017), the species of the subgenus Paramongoma seem associated with the aquatic microhabitats. Gelhaus (2009) offers a synopsis of the subgenus Paramongoma present in Central America, mentioning that larvae and pupae of several species have been found in water and debris that accumulate at the base of bromeliads (Picado 1913; Alexander 1919, 1969), as well as mentioning a species in Puerto
Rico captured from a small mountain stream (Gelhaus et al. 1993; Livingston \& Gelhaus 1994). This agrees with the data given for known Paramongoma species from the Afrotropical region (De Jong 2017). The presence of such microhabitats can, therefore, be inferred as present in the area then occupied by Hispaniolan paleo-island. These specific conditions that caused T. miocenica Mederos \& Wang n. sp. specimens to become trapped in the resin of Hymenaea protera are currently found in the largest islands of the West Indies, including Hispaniola and also in many of the small islands of the area. 


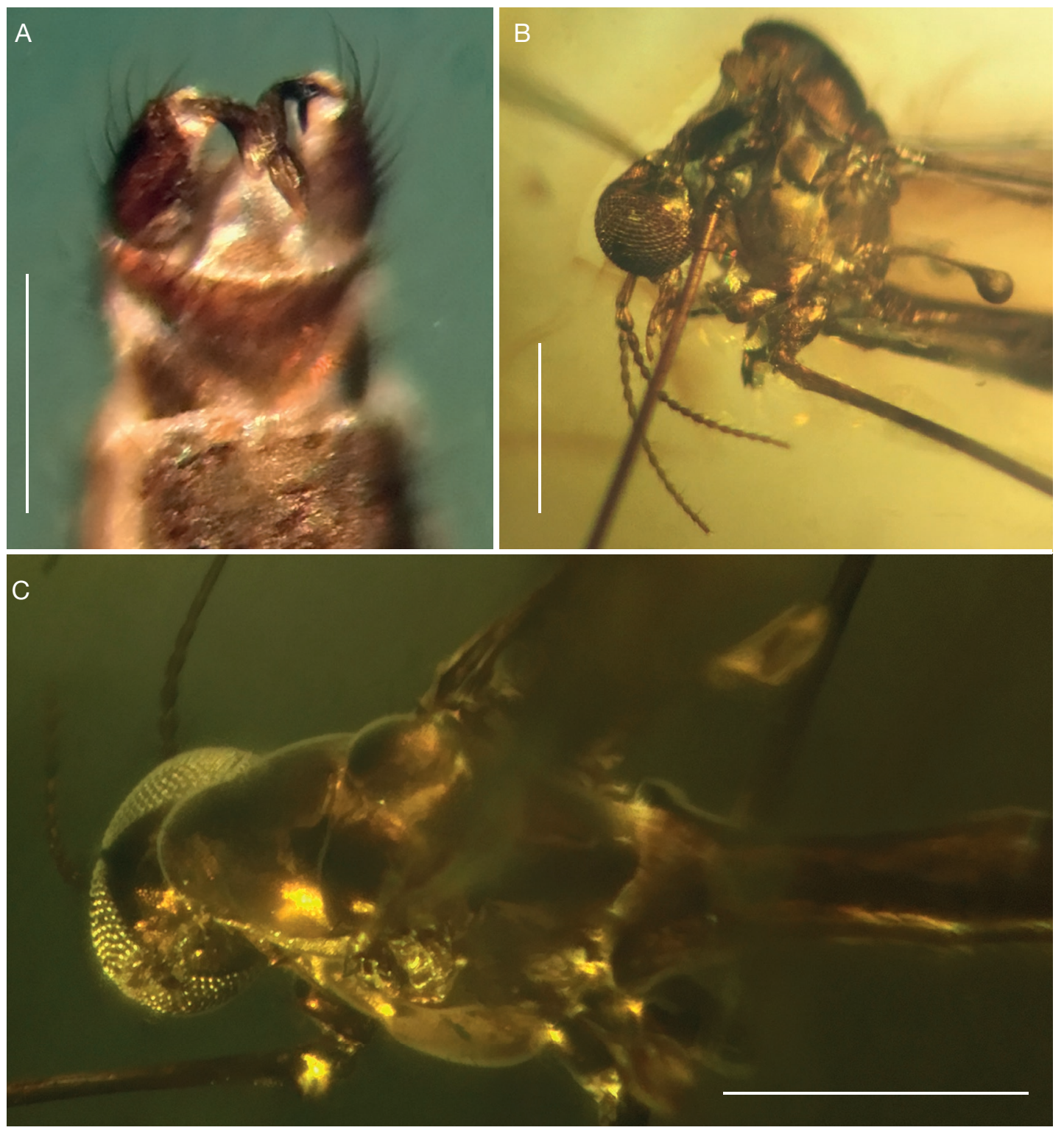

FIG. 4. - Male terminalia (A) of Trentepohlia (P.) miocenica Mederos \& Wang n. sp. holotype specimen. Thorax in lateral (B) and dorsal view (C) of two paratype male specimens. Scale bars: A, $0.2 \mathrm{~mm}$; B, C, $0.5 \mathrm{~mm}$.

This view of wet microhabitats presumably present in the times of T. miocenica Mederos \& Wang n. sp., hypothesized from the specimens studied here, agrees with the data of Grund (2006), inferred as a result of the study of fossil specimens of several genera of Chironomidae (Diptera) present in the Miocene of Hispaniola. According to this author, the taxa analyzed (freshwater organisms) and in particular the genus Xestochironomus Sublette \& Wirth, 1972 and Stenochironomus Kieffer, 1919 prove the persistence of submerged dead wood in nutrient-poor mountain streams in the Greater Antilles from the Miocene until today. Iturralde-Vinent (2001) explained that the presence of plant-derived organic debris in the amber and in the nature of the clastic rocks north of the Hispaniolan paleo-island suggest that the highlands were covered by humid tropical forest, like that existing today on the windward side of higher elevations throughout the
Greater Antilles. Penney (1999, 2005) compared fossil and recent spider families of the region and concluded that the taxa found in amber but not today on Hispaniola still exist on the island but are yet to be found. This persistence of the environments in the area that has been discussed above, offers a possibility of finding the genus Trentepoblia in Hispaniola at present, especially taking into account that several extant species of this taxa are known from the other large and small islands of the Caribbean.

\section{CONCLUSION}

This work is a contribution to the knowledge on the Trentepohlia species of Miocene, particularly those known from Central America. With the description here of a new species 
from resinites of Hispaniola, the number of world fossil species of the subgenus Paramongoma is increased to five. The new species is established mainly on the basis of male genitalia, wing venation and presence of a well-marked stigma, as well on the antennal flagellomeres. Our study supports the hypothesis of previous authors about the persistence since the Miocene of aquatic microhabitats in the area then occupied by Hispaniolan paleo-island. Along with this, the presence of extant species of Trentepohlia (Paramongoma) in other islands of the region offers a high probability of finding an extant species in Hispaniola too.

\section{Acknowledgements}

The authors are indebted to Manuel A. Iturralde-Vinent for his generous support during the first stage of the study, also to Viktor Varanov and André Nel for the review, comments and valuable improvement of the manuscript. To Gloria Masó and Berta Caballero, curators of the MCNB for their constant support and facilities for the study of the samples. To Marta Pérez, Neus Brañas and Sergi Gago (MCNB) for their help in the various technical aspects involved in the handling, treatment and conservation of the pieces studied. To George Poinar for his kindness and to provide us with key bibliography during the study, as well as Marcelo Jimenez for providing the locality information on the amber specimens.

\section{REFERENCES}

AleXander C. P. 1919. - The crane-flies of New York. Part I. Distribution and taxonomy of the adult flies. Memoirs, Cornell University Agricultural Experiment Station 25: 767-993. https:// www.biodiversitylibrary.org/page/9811334

AleXANDER C. P. 1969. - Undescribed Neotropical Trichoceridae and Tipulidae (Diptera). Studia Entomologica (N.S.) 12:341-382.

AleXander C. P. \& AleXAnder M. M. 1970. - Family Tipulidae, in Papavero N. (ed). Catalogue of the Diptera of the Americas South of the United States, Volume 4. Museu de Zoologia da Universidade de São Paulo, São Paulo, 259 p.

Arillo A. \& Ortuño V. M. 2005. - Catalogue of fossil insect species described from Dominican amber (Miocene). Stuttgarter Beiträge zur Naturkunde Serie B 352: 1-68.

Berggren W. A., Kent D. V., Swisher C. C. \& Aubry M. P. 1995. - A revised Cenozoic geochronology and chronostratigraphy. Special Publications Society of Economic Paleontology and Mineralogy 54: 129-212.

Bigot J. M. F. 1854. - Essai d'une classification générale et synoptique de l'ordre des insectes diptères (3e memoire). Tribu de Tipulidii (mihi). Annales de la Société entomologique de France (3) 2: 447-482. https://www.biodiversitylibrary.org/page/8375490

Brouwer S. B. \& Brouwer P. A. 1982. — Geología de la región ambarifera oriental de la República Dominicana. Transactions of the 9th Caribbean Geological Conference, Santo Domingo 1:305-322.

BRUNETTI E. 1911. - Revision of the Oriental Tipulidae with descriptions of new species. Records of the Indian Museum 6: 231-314. https://www.biodiversitylibrary.org/page/11135737

Champetier Y., Madre M., Samama J. C. \& Tavares I. 1982. Localisation de l'ambre au sein des séquences à lignites en République Dominicaine. Transactions of the 9th Caribbean Geological Conference, Santo Domingo 1, 277 p.

Cumming J. M. \& Wood D. M. 2009. — Adult morphology and terminology, in Brown B. V., Borkent A., Cumming J.
M., Wood D. M., Woodley N. E. \& Zumbado M. A. (ed). Manual of Central American Diptera. Volume 1. NRC Research Press, Ottawa, 9-50.

DE JONG H. 2017. - 14. Limoniidae and Tipulidae (crane flies), in KirK-Spriggs A. H. \& Sinclair B. J. (eds). Manual of Afrotropical Diptera. Volume 2. Nematocerous Diptera and lower Brachycera. Suricata 5. South African National Biodiversity Institute, Pretoria: 1-51.

Díaz-Neira J. A., Braga J. C., Mediato J., Lasseur E., Monthel J., García-Sanz J., Hernaiz P. P., PéreZ-Cerdán F. \& Lopera E. 2017. - Evolución paleogeográfica reciente del sector oriental de La Española. Boletín Geológico y Minero 128 (3): 675-693. https://doi.org/10.21701/bolgeomin.128.3.008

EvenHuIS N. L. 2014. - Family Limoniidae, in Catalog of the fossil flies of the world (Insecta: Diptera) website. Available from: http://hbs.bishopmuseum.org/fossilcat/fosslimoniidae.html. Version 16/02/2014 [Accessed on August 2018.]

GelHAus J. K. 2009. - Tipulidae (Crane Flies, Tipúlidos), in Brown B. V., Borkent A., Cumming J. M., WoOd D. M., WoOdley N. E. \& Zumbado M. A. (ed). Manual of Central American Diptera. Volume 1. NRC Research Press, Ottawa, 193-236.

Gelhaus J. K., Masteller E. C. \& Buzby K. M. 1993. - Emergence composition and phenology of Tipulidae (Diptera) from a tropical rainforest stream at El Verde, Puerto Rico. Journal of the Kansas Entomological Society 66: 160-166.

Grimaldi D. A. 1995. - The Age of Dominican Amber, in Andersin and Crelling; Amber, Resinita and Fossil Resins, ACS Symposium Series; American Chemical Society, Washingon DC, 1995: 205-217.

GRUND M. 2006. - Chironomidae (Diptera) in Dominican amber as indicators for ecosystem stability in the Caribbean. Palaeogeography, Palaeoclimatology, Palaeoecology 241: 410-416 https:// doi.org/10.1016/j.palaeo.2006.04.005

ITURRALDE-VINENT M. A. 2001. — Geology of the amber-bearing deposits of the Greater Antilles. Caribbean Journal of Science 37 (3-4), 141-167.

Iturralde-Vinent M. A. \& Hartstein E. 1998. - Miocene amber and lignitic deposits in Puerto Rico. Caribbean Journal of Science 34 (3-4): 308-312.

Iturralde-Vinent M. A. \& MacPhee R. D. E. 1996. — Age and paleogeographical origin of Dominican amber. Science 273, $1850-1852$.

Livingston M. E. \& Gelhaus J. K. 1994. — Further observations on the emergence composition and phenology of craneflies (Diptera: Tipulidae) from a tropical rain forest stream at El Verde, Puerto Rico. Journal of the Kansas Entomological Society 66: 405-410

Mann P., Draper G. \& LeWIS J. F. (Eds) 1991. - Geologic and tectonic development of the North America-Caribbean plate boundary in Hispaniola. Geological Society of America Special Papers, 401 p.

Mederos-López J. \& Gelhaus J. K. 2014. — A new Neotropical species of Trentepohlia (Mongoma) (Diptera: Tipulidae) from Cuba. Transactions of the American Entomological Society 140: 137-144. https://doi.org/10.3157/061.140.0109

Michener C. D. \& PoinAR JR. G. 1996. - The known bee fauna of the Dominican amber. Journal of the Kansas Entomological Society 69 (4), 353-361.

Ngô-Muller V., Garrouste R., Pouillon J.-M., Christophersen V., Christophersen A. \& Nel A. 2019. - The first representative of the fly genus Trentepohlia subgenus Mongoma in amber from the Miocene of Sumatra (Diptera: Limoniidae). Historical Biology. https://doi.org/10.1080/08912963.2019.1610948

OOSTERBROEK P. 2019. - Catalogue of the craneflies of the World (CCW). Available from: http://ccw.naturalis.nl/ [Accessed on January 2019.]

PENNEY D. 1999. - Hypotheses for the recent Hispaniolan spider fauna based on the Dominican Republic amber fauna. Journal of Arachnology 27: 64-70. 
Penney D. 2005. - First fossil Filistatidae: A new species of Misionella in Miocene amber from the Dominican Republic. Journal of Arachnology 33: 93-100. https://doi.org/10.1636/H03-38

PICADO C. 1913. — Les bromeliacées epiphytes. Bulletin scientifique de la France et de la Belgique 47 (3): 215-360.

Podenas S. \& Poinar G. O. 1999. - New crane flies (Diptera: Limoniidae) from Dominican amber. Proceedings of the Entomological Society of Washington 103: 595-610.

Podenas S. \& POINAR G. O. 2001. - New crane flies (Diptera: Tipulidae, Limoniidae) from Dominican and Mexican amber. Proceedings of the Entomological Society of Washington 103: 863-878.

Poinar JR. G. O. \& POINAR R. 1999. - The Amber Forest: A Reconstruction of a Vanished World. Princeton University Press, Princeton, New Jersey.

SCHUMANN W. 2001. - Gemstones of the world. Robert Hale LTD. $228 \mathrm{p}$
Sherratt E., del Rosario Castañeda M., Garwood R. J., Mahler D. L., Sanger T. J., Herrel A., De Queirozh K. \& Losos J. B. 2015. - Amber fossils demonstrate deep-time stability of Caribbean lizard communities. Proceedings of the National Academy of Sciences 112 (32): 9961-9966. https://doi. org/10.1073/pnas. 1506516112

STARY J. 1992. - Phylogeny and classification of Tipulomorpha, with special emphasis on the family Limoniidae. Acta Zoologica Cracoviensia 35: 11-36.

Vaughan T. W., CoOKe W., Condit D. D., Woodring W. P. \& CALKINS F. C. 1922. - A geological reconnaissance of Dominican Republic. Servicio Geológico Republic Dominicana 1, 302 p. https://doi.org/10.5962/bhl.title.15783

WILSON E. O. 1988. - The biogeography of the West Indian ants (Hymenoptera: Formicidae), in LIEBHERR J. K. (ed.), Zoogeography of Caribbean Insects. Cornell University Press, New York: 214-230.

Submitted on 15 May 2019; accepted on 28 January 2020; published on 24 November 2020. 